\title{
Gender and socio-economic issues in the clinical assessment of Orthopaedic patients during the COVID-19 pandemic
}

\author{
Lorenzo Moretti ${ }^{1}$, Davide Bizzoca ${ }^{2}$, Elsa Vitale ${ }^{3}$, Michelangelo Delmedico $^{1}$, Antonio Spinarelli', Azzola Fabio ${ }^{4}$, \\ Giuseppe Solarino ${ }^{1}$ and Biagio Moretti ${ }^{1}$
}

Citation: Moretti L., Bizzoca D.,

Vitale E., Delmedico M., Spinarelli

A., Azzola F., Solarino G., Moretti B.

Gender and socio-economic issues in the clinical assessment of Orthopaedic patients during the COVID-19 pandemic. Life 2021, 11, x.

https://doi.org/10.3390/xxxxx
1 Orthopaedic and Trauma Unit, Department of Basic Medical Sciences, Neuroscience and Sense Organs, School of Medicine, University of Bari Aldo Moro, AOU Consorziale Policlinico, Bari, Italy.

2 University of Bari “Aldo Moro. PhD course in Public Health, Clinical Medicine, and Oncology. Piazza Giulio Cesare 11, 70100 Bari, Italy. E-mail: da.bizzoca@gmail.com

3 Mental Health Center in Modugno, Local Health Company

${ }^{4}$ Istituto Clinico Sant'Anna - Brescia

* Correspondence: Lorenzo Moretti, MD, PhD, Orthopaedic and Trauma Unit, AOU Consorziale Policlinico, Piazza Giulio Cesare 11, 70100 Bari, Italy. E-mail: lorenzo.moretti@libero.it

\begin{abstract}
This observational study aims to depict the impact of gender and socio-economic issues on the health status of Italian Orthopaedic patients during the COVID-19 lockdown. An Ad Hoc questionnaire was developed and online administered. The following data were extracted from the questionnaire: age, body mass index (BMI), education level, distance from hospital, orthopaedic disease, concomitant medical comorbidities, living status (with/without cohabitants) and physical activity level (according to Tegner Activity Scale). The impact of the COVID-19 lockdown was studied analyzing differences related to the above-mentioned parameters.

A significant increase of the call number to general practitioner and to the orthopaedic surgeon was observed during the COVID-lockdown, especially in patients with higher education level. Nonetheless, a reduced compliance in drugs assumption was observed in patients with higher education level during lockdown ( $\mathrm{p}=0.007)$. Almost all the analyzed items were significantly influenced by the distance between patient's domicile and the nearest hospital. However, no significant differences were observed comparing pre-COVID to COVID lockdown.

In the present study patients' gender and education level revealed a significant impact on the social behavior during the COVID lockdown, compared with the pre-COVID period.
\end{abstract}

Keywords: Covid-19 perception; general well-being; orthopaedic patients; gender; pandemic; socioeconomic issues.

\section{Introduction}

In late February 2020, a severe coronavirus disease 2019 (COVID-19) cluster was unexpectedly depicted in Northern Italy. The first the autochthonous case of COVID-19 was diagnosed on February 20th in Codogno (Lodi, Lombardy). In the following 24 hours, thirty-six more new COVID-19 cases, non-directly linked to Codogno Patient-1, were reported in Lombardy and Veneto.

The Italian Council of Ministers quickly put the two COVID-19 outbreak areas on quarantine, thus identifying the so-called "red zones". Nonetheless, in a few days, the virus spread exponentially in Northern Italy and thorough the country. 
Consequently, hospitals become overcrowded, several healthcare professionals become infected and a dramatic increase in mortality rate, among COVID-positive patients with comorbidities, was depicted. Based on these findings, on March 9th, 2020, the Italian government released a new decree, prohibiting travels and movement in public places, except for justifiable work reasons: the whole country was on lockdown.

This new scenario had an unpredictable impact on the mental status of both COVID and non-COVID patients and health-care professionals [1].

Previous studies have reported the Severe Acute Respiratory Syndrome (SARS) epidemic and the H1N1 flu significantly impacted on people mental status[2,3]. Therefore, during the SARS outbreak, several studies investigated the psychological impact of the disease on the non-infected community[4,5]. Older age, female gender and higher education were related to a higher fear of SARS contagion. Moreover, patients with SARS-like symptoms were more likely to take precautionary measures against the infection[6,7].

Currently, there is little information about gender and socio-economic differences in the perception of COVID-19 pandemic. This study aims to depict the impact of gender and socio-economic issues on the health status of Italian Orthopaedic patients during the COVID-19 lockdown.

\section{Materials and Methods}

A prospective multicentric observational study was performed. The study included all the Orthopaedic patients referring to the Orthopaedic emergency departments and Orthopaedic outpatient departments involved in the study, throughout Italy.

All the patients received an invitation to voluntary take part in the study. All the information collected had no diagnostic purposes and the results were treated confidentially, guaranteeing complete anonymity. Each patient completed an online form provided by the Orthopaedic surgeons involved in this multicenter study; all the data were subsequently gathered in a unique anonym database.

An Ad Hoc questionnaire was developed and online administered. The following data were extracted from the questionnaire: age, body mass index (BMI), education level, distance from hospital, orthopaedic disease, concomitant medical comorbidities, living status (with/without cohabitants) and physical activity level (according to Tegner Activity Scale).

All the participants were also asked to describe their relationship with the general practitioner, the orthopaedic surgeon and the Emergency Department during the preCOVID period (November 2019-January 2020) compared to the COVID lockdown period (March-April 2020). Compliance in drugs assumption and in the local therapy (intraarticular injections; shock waves therapy; physiokinesistherapy) administration. The patients' frequency in looking for info about your health condition on the net and fear of COVID19 infection were also investigated.

The impact of the COVID-19 lockdown was studied analyzing differences related to gender, age, education level, distance from hospital, number of medical comorbidities and living status.

Statistical analysis was performed using SPSS (version 20; IBM Corp, Armonk, NY). Descriptive statistics were used to evaluate the sample demographic characteristics. The Chi-square test and Fisher's exact test were used to assess the variability between groups.

Kruskal-Wallis test was performed to assess the variability between subgroups. The tests were two-tailed; statistical significance was set at $\mathrm{p}<0.05$. 
The main data of the study are summarized in table 1.782 patients completed the $\mathrm{Ad}$ Hoc questionnaire (male: 422; female:360; mean age: 59.77 y. o.).

Table 2 shows gender- and age-related differences between pre-COVID and COVID lockdown period. No significant differences between genders and different age subgroups were depicted.

Table 3 summarizes gender- and education level-related differences between preCOVID and COVID lockdown period. A significant increase of the call number to general practitioner and to the orthopaedic surgeon was observed during the COVID-lockdown, especially in patients with higher education level. Nonetheless, a reduced compliance in drugs assumption was observed in patients with higher education level during lockdown $(\mathrm{p}=0.007)$.

Table 4 shows the results of the gender-specific analysis with reference to patients' distance from hospital. Almost all the analyzed items were significantly influenced by the distance between patient's domicile and the nearest hospital. However, no significant differences were observed comparing pre-COVID to COVID lockdown.

Table 5 focuses on the analysis of patients' comorbidities. No significant differences were depicted.

Table 6 summarizes gender- and living status-related analysis. No significant differences were observed.

Table 1. Main data of the study.

\begin{tabular}{|c|c|c|c|c|}
\hline & All $(n ; \%)$ & Female $(\mathrm{n} ; \%)$ & Male (n;\%) & $p$ value \\
\hline Patients, n (\%) & $\mathrm{n}=782 ; 100 \%$ & $360 ; 46.04 \%$ & $422 ; 53.96 \%$ & \\
\hline \multicolumn{4}{|l|}{ Age } & .061 \\
\hline $18-35$ years, n (\%) & 22 & 12 & 10 & \\
\hline $36-50$ years, n (\%) & 58 & 36 & 22 & \\
\hline 51-65 years, n (\%) & 325 & 145 & 180 & \\
\hline$>65$ years, n (\%) & 377 & 167 & 210 & \\
\hline \multicolumn{4}{|l|}{ Education } & $.006^{*}$ \\
\hline$<$ High school & 72 & 46 & 26 & \\
\hline High school & 64 & 30 & 34 & \\
\hline Degree & 646 & 284 & 362 & \\
\hline Distance from hospital & & & & .086 \\
\hline$<2 \mathrm{~km}$ & 342 & 152 & 190 & \\
\hline $2-10 \mathrm{~km}$ & 256 & 125 & 131 & \\
\hline $10-20 \mathrm{~km}$ & 39 & 24 & 15 & \\
\hline$>20 \mathrm{~km}$ & 145 & 59 & 86 & \\
\hline \multicolumn{4}{|l|}{ Orthopaedic disease } & .454 \\
\hline Trauma & 144 & 63 & 81 & \\
\hline Osteoporosis & 153 & 68 & 85 & \\
\hline Osteoarthritis & 164 & 83 & 81 & \\
\hline Muscle/tendon diseases & 156 & 65 & 91 & \\
\hline
\end{tabular}




\begin{tabular}{|c|c|c|c|c|}
\hline Spine diseases & 165 & 81 & 84 & \\
\hline \multicolumn{4}{|c|}{$\begin{array}{l}\text { Medical comorbidities } \\
\text { (i.e., obesity, diabetes, hypertension, dyslipidaemia, ischemic heart disease, COPD, malignancies) }\end{array}$} & .151 \\
\hline None & 542 & 251 & 291 & \\
\hline 1 & 206 & 91 & 115 & \\
\hline 2 & 17 & 6 & 11 & \\
\hline$>2$ & 17 & 12 & 5 & \\
\hline \multicolumn{4}{|l|}{ Living status } & $.031^{*}$ \\
\hline Alone & 173 & 77 & 96 & \\
\hline With 1 or more roommates & 314 & 142 & 172 & \\
\hline With wife or husband & 111 & 65 & 46 & \\
\hline $\begin{array}{l}\text { With wife/husband and } \\
\text { children }\end{array}$ & 184 & 76 & 108 & \\
\hline \multicolumn{5}{|l|}{ Physical activity level: } \\
\hline $\begin{array}{l}\text { Level 0: Illness or disability } \\
\text { pension }\end{array}$ & 13 & 9 & 4 & $<.001^{*}$ \\
\hline Level 1: Sedentary work & 199 & 102 & 97 & \\
\hline $\begin{array}{l}\text { Level 2: Light work or walks } \\
\text { on uneven ground but } \\
\text { impossible excursions }\end{array}$ & 105 & 53 & 52 & \\
\hline Level 3: Light jobs & 131 & 69 & 62 & \\
\hline Level 4: Moderate heavy work & 56 & 28 & 28 & \\
\hline $\begin{array}{l}\text { Level 5: Heavy work, } \\
\text { competitive sport-cycling, } \\
\text { cross-country skiing, } \\
\text { recreational sport, jogging on } \\
\text { uneven ground at least } 2 \text { times } \\
\text { a week }\end{array}$ & 118 & 49 & 69 & \\
\hline $\begin{array}{l}\text { Level 6: Recreational sport, } \\
\text { tennis and badminton, } \\
\text { handball, racquetball, skiing } \\
\text { (downhill), jogging at least } 5 \\
\text { times a week }\end{array}$ & 96 & 35 & 61 & \\
\hline $\begin{array}{l}\text { Level 7: Competitive sport- } \\
\text { tennis, running, handball, } \\
\text { recreational sport, soccer, } \\
\text { football, rugby, ice hockey, } \\
\text { basketball, squash, racquetball, } \\
\text { running }\end{array}$ & 41 & 10 & 31 & \\
\hline $\begin{array}{l}\text { Level 8: Competitive sport, } \\
\text { racquetball, bandy, squash }\end{array}$ & 4 & 0 & 4 & \\
\hline
\end{tabular}




\begin{tabular}{|c|c|c|c|}
\hline $\begin{array}{l}\text { or badminton, athletics, } \\
\text { skiing (downhill) }\end{array}$ & & & \\
\hline $\begin{array}{l}\text { Level 9: Competitive sport, } \\
\text { soccer, football, rugby } \\
\text { (lower leagues), ice } \\
\text { hockey, wrestling, } \\
\text { gymnastics, basketball }\end{array}$ & 15 & 5 & 10 \\
\hline $\begin{array}{l}\text { Level 10: National } \\
\text { competitive sport, soccer, } \\
\text { football, rugby }\end{array}$ & 4 & 0 & 4 \\
\hline
\end{tabular}

Table 2. Gender and age-related analysis

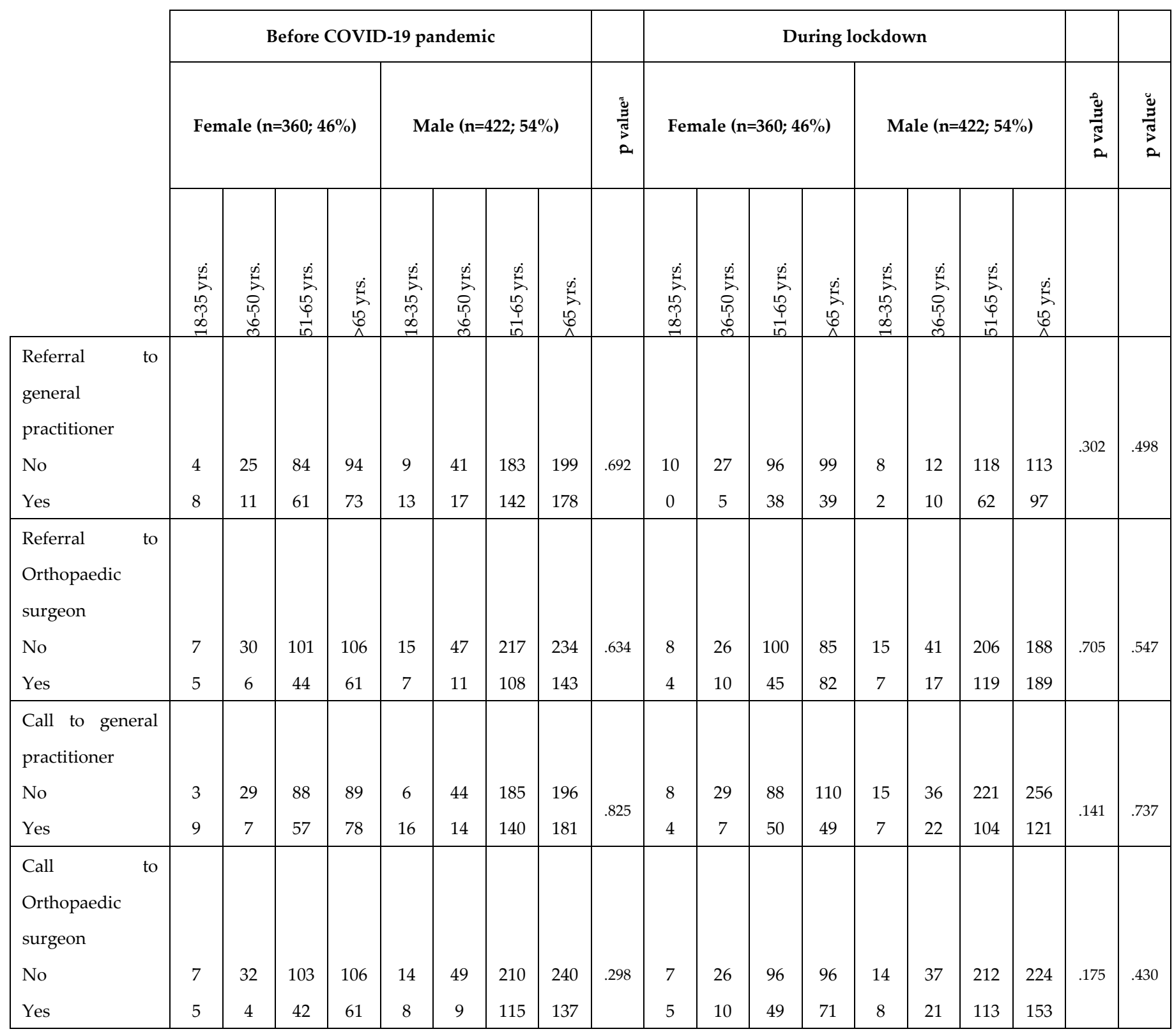




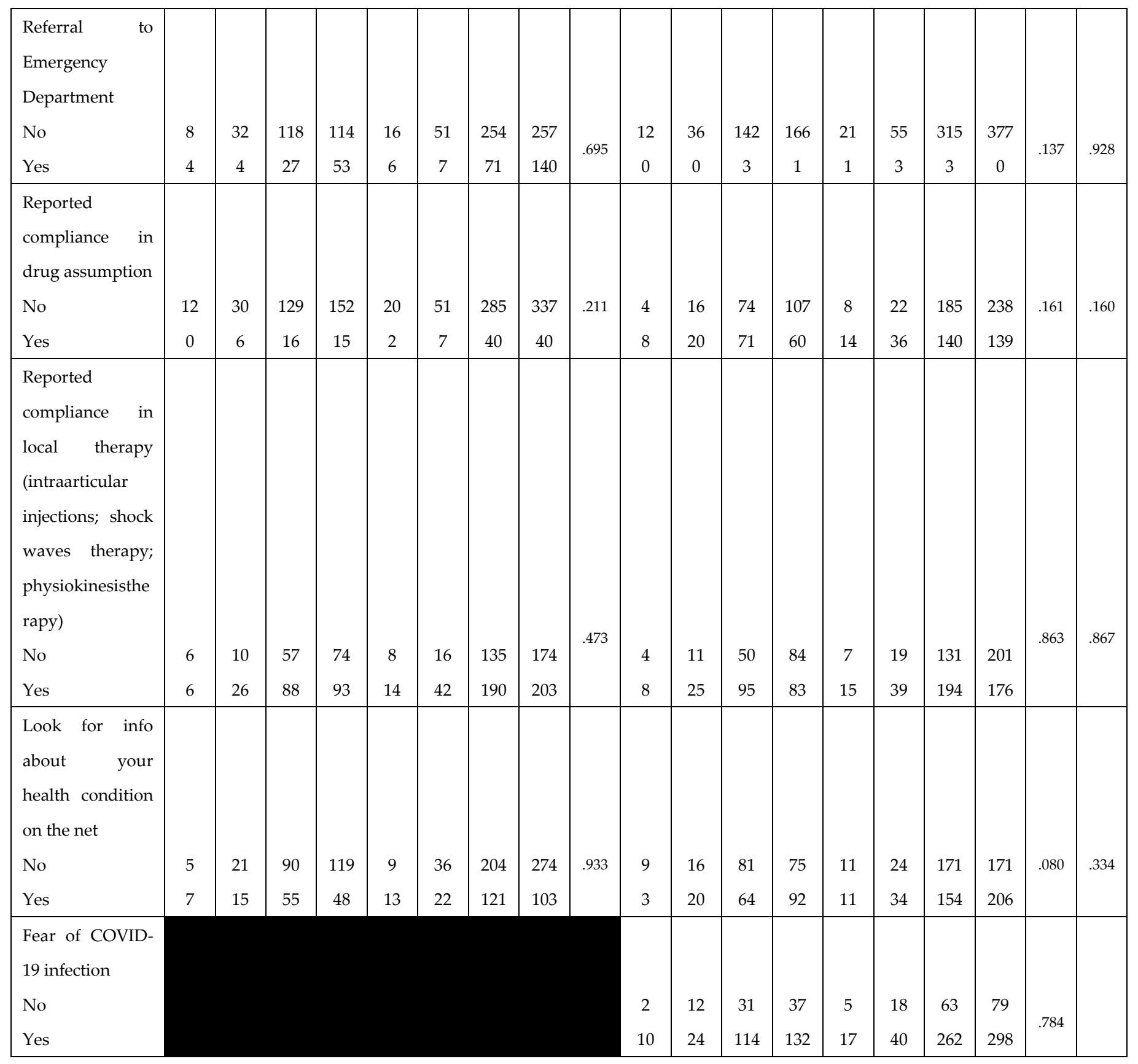

$\mathrm{a}=$ Multivariate Analysis between Females and Males Before COVID-19 pandemic; $\mathrm{b}=$ Multivariate Analysis between Females and Males During lockdown; $\mathrm{c}=$ Multivariate Analysis between Females and Males and Before and During COVID-19 pandemic; ${ }^{*}=\mathrm{p}$ value $<0.05$. 
Table 3. Gender and education level

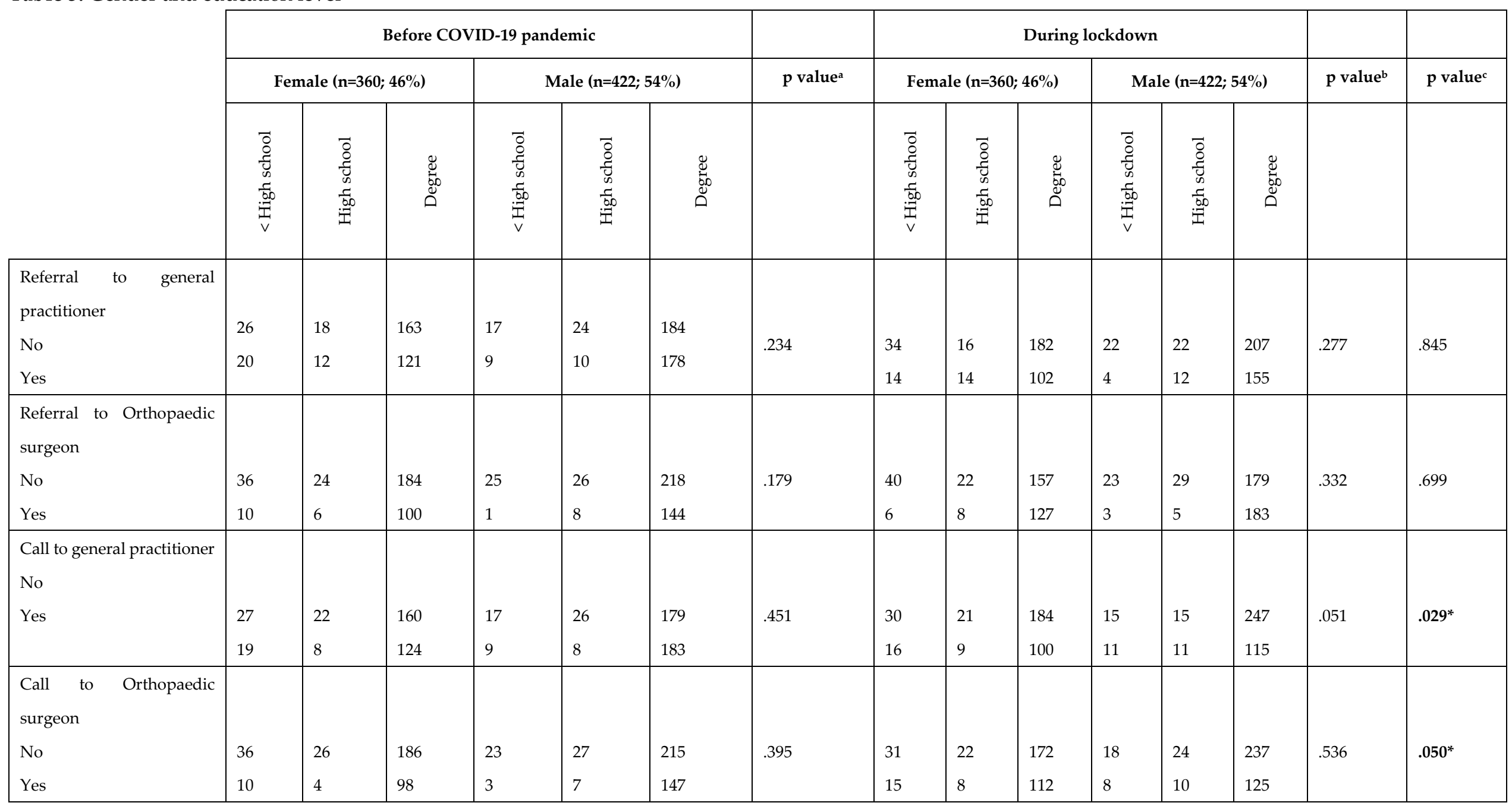




\begin{tabular}{|c|c|c|c|c|c|c|c|c|c|c|c|c|c|c|c|}
\hline $\begin{array}{l}\text { Referral to Emergency } \\
\text { Department } \\
\text { No } \\
\text { Yes }\end{array}$ & $\begin{array}{l}43 \\
3\end{array}$ & 28 & $\begin{array}{l}201 \\
83\end{array}$ & $\begin{array}{l}26 \\
0\end{array}$ & 32 & $\begin{array}{l}248 \\
114\end{array}$ & .716 & 45 & $\begin{array}{l}29 \\
1\end{array}$ & $\begin{array}{l}282 \\
2\end{array}$ & $\begin{array}{l}26 \\
0\end{array}$ & $\begin{array}{l}34 \\
0\end{array}$ & $\begin{array}{l}348 \\
14\end{array}$ & .228 & 916 \\
\hline $\begin{array}{l}\text { Reported compliance in } \\
\text { drug assumption } \\
\text { No } \\
\text { Yes }\end{array}$ & $\begin{array}{l}38 \\
8\end{array}$ & 26 & $\begin{array}{l}259 \\
25\end{array}$ & $\begin{array}{l}19 \\
7\end{array}$ & 30 & $\begin{array}{l}321 \\
41\end{array}$ & .587 & 24 & $\begin{array}{l}18 \\
12\end{array}$ & $\begin{array}{l}161 \\
123\end{array}$ & $\begin{array}{l}13 \\
13\end{array}$ & $\begin{array}{l}8 \\
26\end{array}$ & $\begin{array}{l}231 \\
131\end{array}$ & $.003^{*}$ & $.007^{*}$ \\
\hline $\begin{array}{l}\text { Reported compliance in } \\
\text { local therapy } \\
\text { (intraarticular injections; } \\
\text { shock waves therapy; } \\
\text { physiokinesistherapy) } \\
\text { No } \\
\text { Yes }\end{array}$ & $\begin{array}{l}14 \\
32\end{array}$ & 21 & $\begin{array}{l}124 \\
160\end{array}$ & $\begin{array}{l}8 \\
18\end{array}$ & 24 & $\begin{array}{l}168 \\
194\end{array}$ & .954 & 35 & $\begin{array}{l}3 \\
27\end{array}$ & $\begin{array}{l}135 \\
149\end{array}$ & $\begin{array}{l}2 \\
24\end{array}$ & $\begin{array}{l}5 \\
29\end{array}$ & $\begin{array}{l}202 \\
160\end{array}$ & .139 & .457. \\
\hline $\begin{array}{l}\text { Look for info about your } \\
\text { health condition on the net } \\
\text { No } \\
\text { Yes }\end{array}$ & $\begin{array}{l}23 \\
23\end{array}$ & $\begin{array}{l}15 \\
15\end{array}$ & $\begin{array}{l}197 \\
87\end{array}$ & $\begin{array}{l}10 \\
16\end{array}$ & 17 & $\begin{array}{l}261 \\
101\end{array}$ & . 488. & 11 & $\begin{array}{l}3 \\
27\end{array}$ & $\begin{array}{l}135 \\
149\end{array}$ & $\begin{array}{l}17 \\
9\end{array}$ & $\begin{array}{l}14 \\
20\end{array}$ & $\begin{array}{l}165 \\
197\end{array}$ & .450 & .239 \\
\hline $\begin{array}{l}\text { Fear of COVID-19 } \\
\text { infection } \\
\text { No } \\
\text { Yes }\end{array}$ & & & & & & & & 29 & 23 & $\begin{array}{l}57 \\
227\end{array}$ & $\begin{array}{l}8 \\
18\end{array}$ & $\begin{array}{l}9 \\
25\end{array}$ & $\begin{array}{l}67 \\
295\end{array}$ & .808 & \\
\hline
\end{tabular}

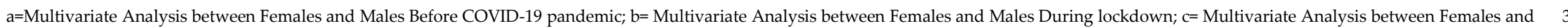

Males and Before and During COVID-19 pandemic; ${ }^{*}=p$ value $<0.05$.

?


Table 4. Gender and distance from hospital

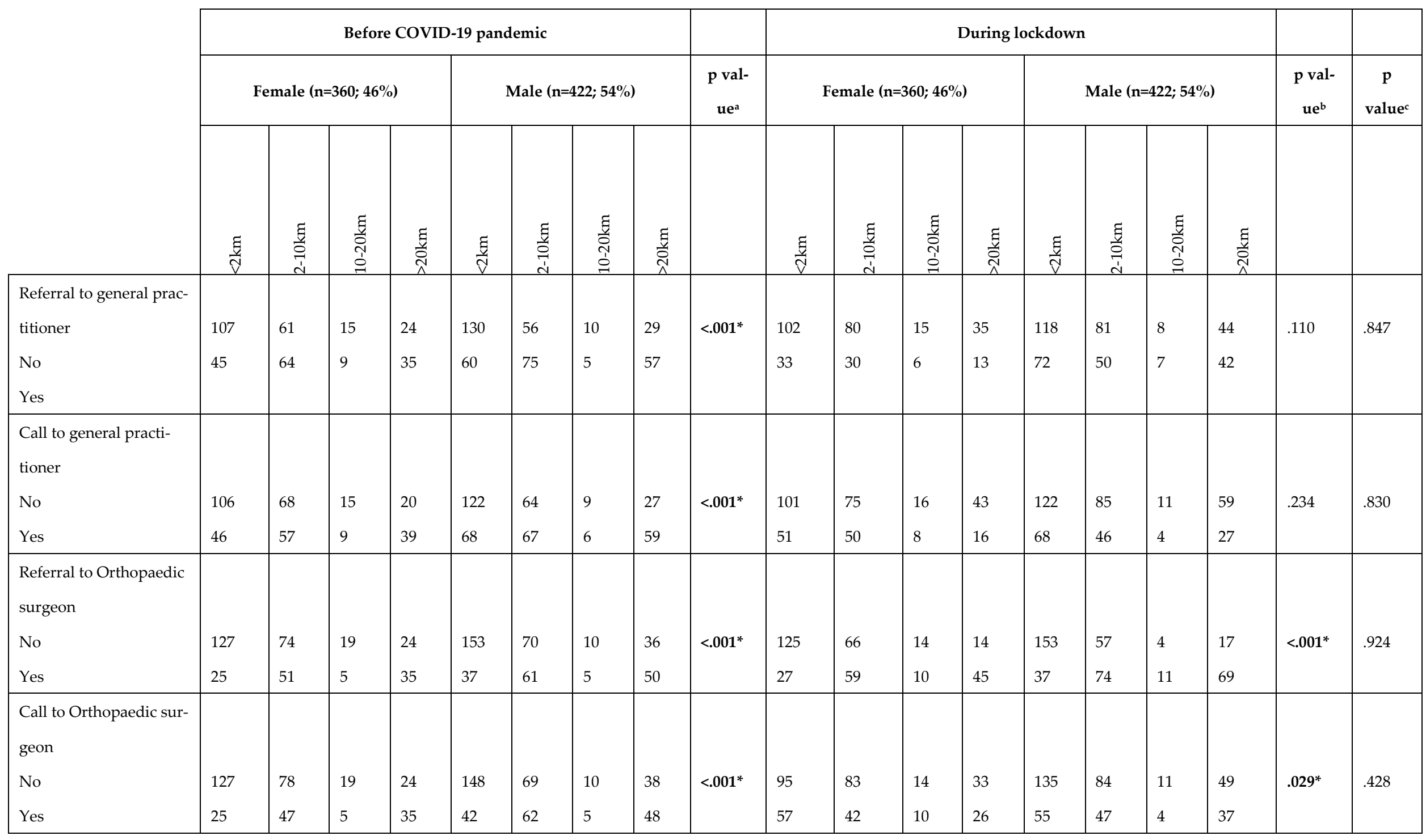




\begin{tabular}{|l|l|l|l|l|l|l|l|l|l|l|l|l|}
\hline Yes & & 109 & 100 & 15 & 55 & 135 & 115 & 12 & 76 & \\
\hline
\end{tabular}

$\mathrm{a}=$ Multivariate Analysis between Females and Males Before COVID-19 pandemic; $b=$ Multivariate Analysis between Females and Males During lockdown; $\mathrm{c}=$ Multivariate Analysis between Females and Males and Before and During COVID-19 pandemic; ${ }^{*}=\mathrm{p}$ value $<0.05$.

Table 5. Gender and medical comorbidities (i.e., obesity, diabetes, hypertension, dyslipidaemia, ischemic heart disease, COPD, malignancies)

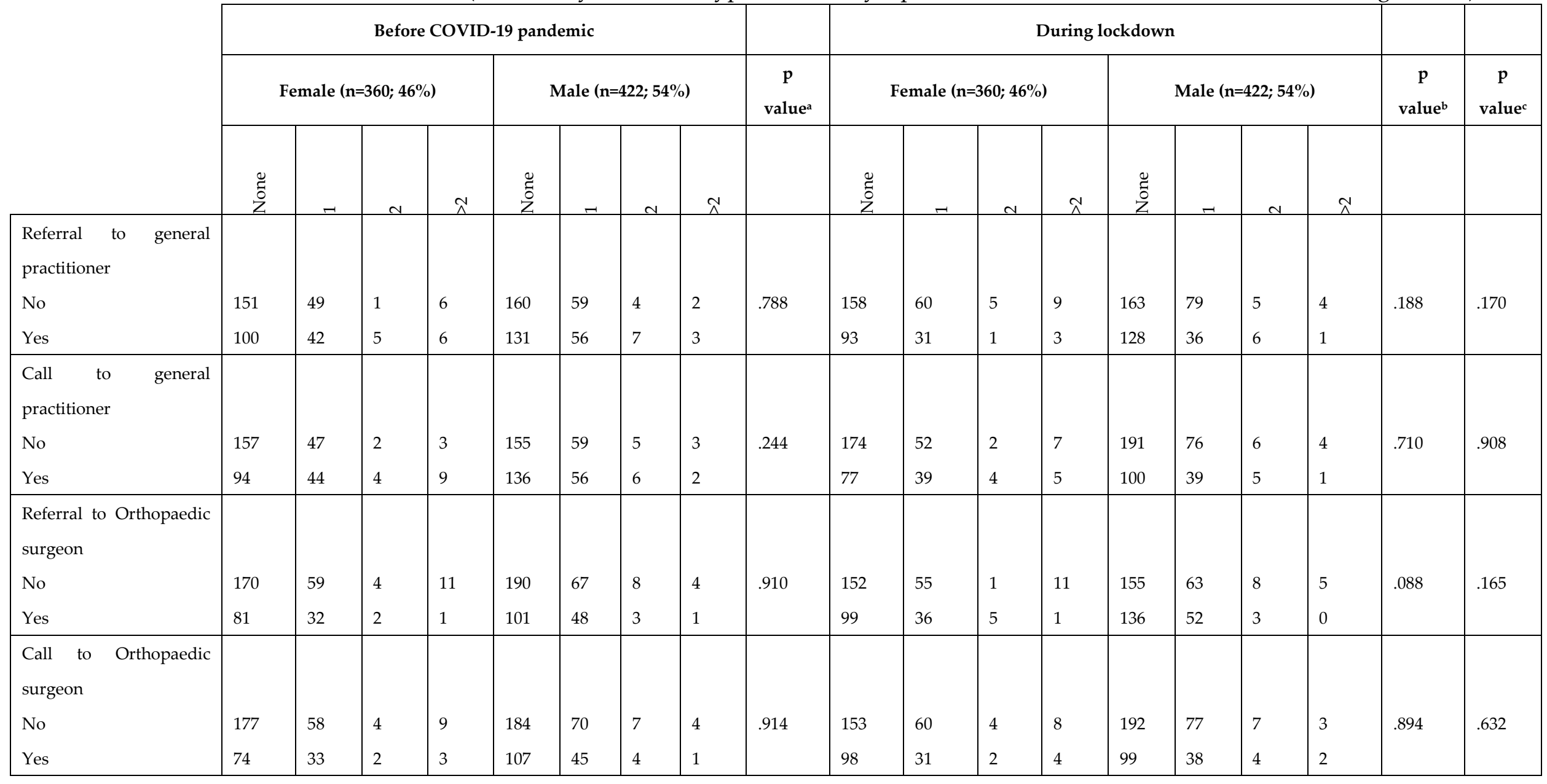




\begin{tabular}{|c|c|c|c|c|c|c|c|c|c|c|c|c|c|c|c|c|c|c|c|}
\hline $\begin{array}{l}\text { Referral to Emergency } \\
\text { Department } \\
\text { No } \\
\text { Yes }\end{array}$ & $\begin{array}{l}189 \\
62\end{array}$ & 24 & 2 & 12 & $\begin{array}{l}211 \\
80\end{array}$ & $\begin{array}{l}80 \\
35\end{array}$ & 10 & 0 & . 677. & $\begin{array}{l}250 \\
1\end{array}$ & $\begin{array}{l}89 \\
2\end{array}$ & 0 & $\begin{array}{l}11 \\
1\end{array}$ & $\begin{array}{l}282 \\
9\end{array}$ & $\begin{array}{l}111 \\
4\end{array}$ & $\begin{array}{l}10 \\
1\end{array}$ & 0 & .552 & .532 \\
\hline $\begin{array}{l}\text { Reported compliance in } \\
\text { drug assumption } \\
\text { No } \\
\text { Yes }\end{array}$ & $\begin{array}{l}221 \\
30\end{array}$ & 87 & 5 & 10 & $\begin{array}{l}259 \\
32\end{array}$ & $\begin{array}{l}99 \\
16\end{array}$ & 8 & 4 & .231 & $\begin{array}{l}134 \\
117\end{array}$ & $\begin{array}{l}50 \\
117\end{array}$ & 6 & $\begin{array}{l}11 \\
1\end{array}$ & $\begin{array}{l}170 \\
121\end{array}$ & $\begin{array}{l}70 \\
45\end{array}$ & 8 & 4 & .560 & .522 \\
\hline $\begin{array}{l}\text { Reported compliance in } \\
\text { local therapy } \\
\text { (intraarticular injections; } \\
\text { shock waves therapy; } \\
\text { physiokinesistherapy) } \\
\text { No } \\
\text { Yes }\end{array}$ & $\begin{array}{l}97 \\
154\end{array}$ & 43 & 2 & 3 & $\begin{array}{l}124 \\
167\end{array}$ & $\begin{array}{l}58 \\
57\end{array}$ & 3 & 1 & .392 & $\begin{array}{l}107 \\
144\end{array}$ & $\begin{array}{l}37 \\
54\end{array}$ & 4 & $\begin{array}{l}1 \\
11\end{array}$ & $\begin{array}{l}147 \\
144\end{array}$ & $\begin{array}{l}57 \\
58\end{array}$ & $\begin{array}{l}4 \\
7\end{array}$ & 1 & .507 & 986 \\
\hline $\begin{array}{l}\text { Look for info about your } \\
\text { health condition on the } \\
\text { net } \\
\text { No } \\
\text { Yes }\end{array}$ & $\begin{array}{l}164 \\
87\end{array}$ & 62 & 4 & 5 & $\begin{array}{l}20 \\
88\end{array}$ & 79 & 5 & 1 & .525 & 119 & 50 & 3 & 9 & $\begin{array}{l}132 \\
159\end{array}$ & $\begin{array}{l}55 \\
60\end{array}$ & 5 & 4 & .923 & .739 \\
\hline $\begin{array}{l}\text { Fear of COVID-19 } \\
\text { infection } \\
\text { No } \\
\text { Yes }\end{array}$ & & & & & & & & & & 197 & 23 & 1 & 3 & 237 & 28 & 10 & 1 & .983 & \\
\hline
\end{tabular}

$\mathrm{a}=$ Multivariate Analysis between Females and Males Before COVID-19 pandemic; $b=$ Multivariate Analysis between Females and Males During lockdown; $c=$ Multivariate Analysis between Females and Males and Before and During COVID-19 pandemic; ${ }^{*}=\mathrm{p}$ value $<0.05$. 
Table 6. Gender and living status

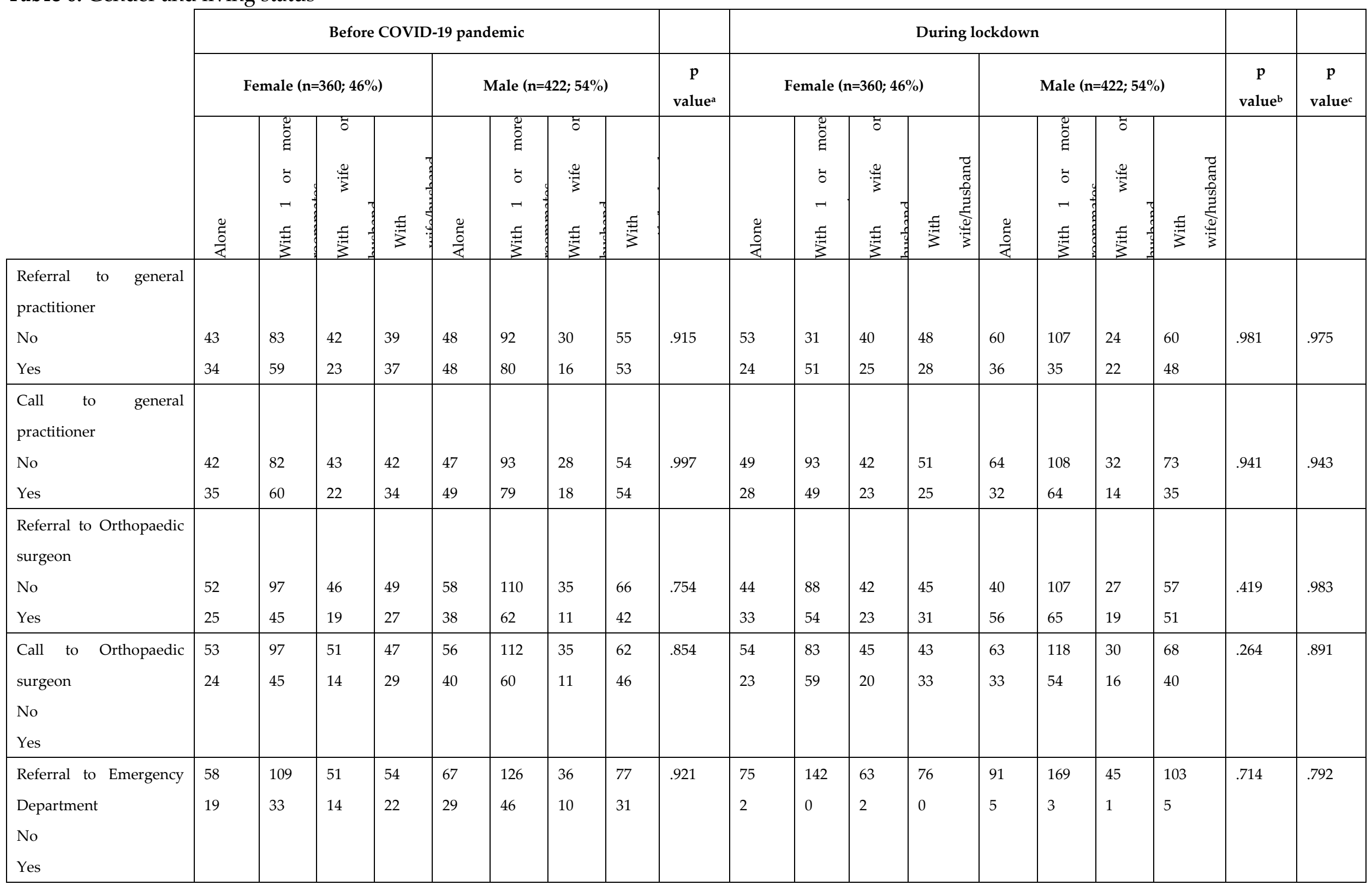




\begin{tabular}{|c|c|c|c|c|c|c|c|c|c|c|c|c|c|c|c|c|c|c|c|}
\hline $\begin{array}{l}\text { Reported compliance in } \\
\text { drug assumption } \\
\text { No } \\
\text { Yes }\end{array}$ & 70 & $\begin{array}{l}125 \\
17\end{array}$ & $\begin{array}{l}60 \\
5\end{array}$ & $\begin{array}{l}68 \\
8\end{array}$ & $\begin{array}{l}83 \\
13\end{array}$ & $\begin{array}{l}152 \\
20\end{array}$ & 42 & 15 & .856 & $\begin{array}{l}49 \\
28\end{array}$ & $\begin{array}{l}79 \\
63\end{array}$ & 31 & $\begin{array}{l}39 \\
37\end{array}$ & $\begin{array}{l}67 \\
29\end{array}$ & $\begin{array}{l}100 \\
72\end{array}$ & $\begin{array}{l}25 \\
21\end{array}$ & $\begin{array}{l}60 \\
48\end{array}$ & 980 & .878 \\
\hline $\begin{array}{l}\text { Reported compliance in } \\
\text { local therapy } \\
\text { (intraarticular injections; } \\
\text { shock waves therapy; } \\
\text { physiokinesistherapy) } \\
\text { No } \\
\text { Yes }\end{array}$ & 30 & $\begin{array}{l}62 \\
80\end{array}$ & $\begin{array}{l}22 \\
43\end{array}$ & $\begin{array}{l}33 \\
43\end{array}$ & $\begin{array}{l}48 \\
48\end{array}$ & $\begin{array}{l}71 \\
101\end{array}$ & $\begin{array}{l}17 \\
29\end{array}$ & $\begin{array}{l}50 \\
58\end{array}$ & .566 & $\begin{array}{l}6 \\
41\end{array}$ & $\begin{array}{l}59 \\
83\end{array}$ & $\begin{array}{l}22 \\
43\end{array}$ & $\begin{array}{l}32 \\
44\end{array}$ & $\begin{array}{l}57 \\
39\end{array}$ & $\begin{array}{l}74 \\
92\end{array}$ & $\begin{array}{l}22 \\
24\end{array}$ & $\begin{array}{l}56 \\
52\end{array}$ & .542 & .952 \\
\hline $\begin{array}{l}\text { Look for info about your } \\
\text { health condition on the } \\
\text { net } \\
\text { No } \\
\text { Yes }\end{array}$ & $\begin{array}{l}46 \\
31\end{array}$ & $\begin{array}{l}94 \\
48\end{array}$ & $\begin{array}{l}42 \\
23\end{array}$ & $\begin{array}{l}53 \\
23\end{array}$ & $\begin{array}{l}67 \\
29\end{array}$ & $\begin{array}{l}112 \\
60\end{array}$ & $\begin{array}{l}34 \\
12\end{array}$ & 33 & .526 & $\begin{array}{l}40 \\
37\end{array}$ & $\begin{array}{l}79 \\
63\end{array}$ & $\begin{array}{l}31 \\
34\end{array}$ & $\begin{array}{l}31 \\
45\end{array}$ & $\begin{array}{l}46 \\
50\end{array}$ & $\begin{array}{l}82 \\
90\end{array}$ & 25 & 61 & .722 & .681. \\
\hline $\begin{array}{l}\text { Fear of COVID-19 } \\
\text { infection } \\
\text { No } \\
\text { Yes }\end{array}$ & & & & & & & & & & $\begin{array}{l}20 \\
57\end{array}$ & $\begin{array}{l}24 \\
118\end{array}$ & $\begin{array}{l}19 \\
46\end{array}$ & $\begin{array}{l}18 \\
58\end{array}$ & $\begin{array}{l}19 \\
77\end{array}$ & $\begin{array}{l}38 \\
134\end{array}$ & $\begin{array}{l}8 \\
38\end{array}$ & $\begin{array}{l}19 \\
89\end{array}$ & .183 & \\
\hline
\end{tabular}

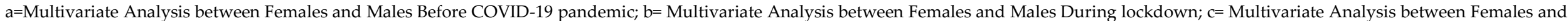
Males and Before and During COVID-19 pandemic; ${ }^{*}=p$ value $<0.05$. 


\section{Discussion}

At the beginning of the second decade of the 21st century, in the era of Medicine 4.0, the health care systems worldwide fought the COVID-19 challenge. Italy was the first country to lockdown in Europe, to struggle with the new coronavirus diffusion. This choice revealed useful in flattening the COVID-19 curve but revolutionized several aspects of our lives.

Ruggieri et al. [8] have investigated the impact of gender differences on the COVID19 infection in Italy, depicting a higher mortality rate in male patients $(14.8 \%)$ compared with female patients (8.2\%). These Authors suggest both biological - i.e., sexual hormones, X-linked genes expression and differential ACE2 expression levels- and lifestyle differences might explain these gender-related differences.

Moreover, Galasso et al. [9] analysed data from a survey conducted in March and April 2020 in eight Organization for Economic Co-operation and Development countries $(n=21,649)$ to study gender differences in COVID-19-related beliefs and behaviours. These Authors showed that women are more likely to perceive COVID-19 as a very serious health problem, to agree with restraining public policy measures, and to comply with them.

This study has focused on the analysis of gender and socio-economic issues in the clinical assessment of Orthopaedic patients during COVID-19 lockdown, compared with the pre-COVID-19 period. Gender, age, education level, distance from hospital, number of medical comorbidities and living status were analyzed. Gender and education level reveal the most relevant factors liable to influence the patients' social behavior during the COVID lockdown, compared to the pre-COVID period. Patients' domicile distance from the nearest hospital also had a relevant impact on the patients' behavior, but no significant differences were observed during COVID lockdown, compared to pre-covid period.

Concerning the perceived risk to contract the COVID-19 infection, Abrams et al. (17) have emphasized the role of risk communication during the COVID pandemic. Therefore, the fear of contracting the COVID-19 disease is as real as the physical danger itself. The present study highlighted there are some aspects of the pandemics that can heighten the risk perception, i.e.; the so-called dread factors, that largely apply to the current pandemic. These factors include high infection rates, the COVID significant morbidity and mortality, the low availability of face masks and personal safety devices, the lack of therapeutic measures and the rapid virus spread.

These factors could underestimate the perception of risk among the general population and, at the same time, they could also underestimate the importance of compliance with the restriction rules. Our data confirm the findings reported by Abrams et al.[10], since the vast majority $(71.22 \%)$ of participants, in absence of gender differences ( $\mathrm{p}=0.082)$, reported a quite high contagion perception risk.

Furthermore, Abrams et al. have also emphasized that daily headlines generate widespread fear and panic; and the World Health Organization (WHO) reported a significant part of effective communication risk includes the identification and management of rumors and misinformation. In this context, our data support the reported by Abrams et al., since 304 women (38.87\%) and 264 men (33.76\%) affirmed they had a medium-high level of fear to contract the infection. This finding has probably promoted the respect of the limitations imposed by the Italian government: 355 women (45.40\%) and 411 men (52.56\%) affirmed they paid attention in adopting all the measures needed to reduce the risk of SARS-CoV-2 infection.

Jungmann et al.[11], moreover, highlighted health anxiety and cyberchondria has increased the SARS-CoV-2 anxiety. Jungmann et al. also observed anxiety is negatively related to the degree of information about the pandemic status. Our data agree with this 
finding, since the participants' psychological level is good as well as the perception that the participants have of their level of information on the pandemic condition.

The findings reported in the present study are useful to plan future public health policies in order to improve patients' care and optimize patients' compliance.

\section{Conclusions}

In the present study patients' gender and education level revealed a significant impact on the social behavior during the COVID lockdown, compared with the pre-COVID period. Patients' domicile distance from the nearest hospital also play an important role in influencing patients' behavior and clinical compliance. These findings are useful to better plan future public health policies.

Author Contributions: Conceptualization, M.B., M.L. and B.D.; methodology, M.B, M.L. and B.D..; software, A.S., G.S, M.D.; data curation, V.E., A.Z.; writing-original draft preparation, B.D; writing - review and editing, B.D., M.B. All authors have read and agreed to the published version of the manuscript.".

Funding: This research received no external funding.

Institutional Review Board Statement: The study was conducted according to the guidelines of the Declaration of Helsinki and approved by the Ethics Committee of AOU POLICLINICO DI BARI (protocol code 6475; date of approval: July 22 ${ }^{\text {nd }}, 2020$ ).

Informed Consent Statement: Informed consent was obtained from all subjects involved in the study.

Data Availability Statement: Data available on request due to privacy restrictions.

Acknowledgments: None.

Conflicts of Interest: The authors declare no conflict of interest.

\section{References}

1. Bettinsoli, M.L.; Di Riso, D.; Napier, J.L.; Moretti, L.; Bettinsoli, P.; Delmedico, M.; Piazzolla, A.; Moretti, B. Mental Health Conditions of Italian Healthcare Professionals during the COVID-19 Disease Outbreak. Appl. Psychol. Heal. Well-Being 2020, 12, 1054-1073, doi:10.1111/aphw.12239.

2. Aoyagi, Y.; Beck, C.R.; Dingwall, R.; Nguyen-Van-Tam, J.S. Healthcare workers' willingness to work during an influenza pandemic: A systematic review and meta-analysis. Influenza Other Respi. Viruses 2015, 9, 120-130.

3. Wu, P.; Fang, Y.; Guan, Z.; Fan, B.; Kong, J.; Yao, Z.; Liu, X.; Fuller, C.J.; Susser, E.; Lu, J.; et al. The psychological impact of the SARS epidemic on hospital employees in China: Exposure, risk perception, and altruistic acceptance of risk. Can. J. Psychiatry 2009, 54, 302-311, doi:10.1177/070674370905400504.

4. Martin, R.C.; Dahlen, E.R. Cognitive emotion regulation in the prediction of depression, anxiety, stress, and anger. Pers. Individ. Dif. 2005, 39, 1249-1260, doi:10.1016/j.paid.2005.06.004.

5. Schimmenti, A.; Billieux, J.; Starcevic, V. The four horsemen of fear: An integrated model of understanding fear experiences during the COVID-19 pandemic. Clin. Neuropsychiatry 2020, 17, 41-45, doi:10.36131/CN20200202.

6. Moghanibashi-Mansourieh, A. Assessing the anxiety level of Iranian general population during COVID-19 outbreak. Asian J. Psychiatr. 2020, 51, doi:10.1016/j.ajp.2020.102076.

7. Purohit, V.; Kudale, A.; Sundaram, N.; Joseph, S.; Schaetti, C.; Weiss, M.G. Public health policy and experience of the 2009 H1N1 influenza pandemic in Pune, India. Int. J. Heal. Policy Manag. 2018, 7, 154-166, doi:10.15171/ijhpm.2017.54.

8. Ruggieri, A.; Gagliardi, M.C. Gender differences in covid-19: Some open questions. Ital. J. Gender-Specific Med. 2020,6 , 49-50. 
9. Galasso, V.; Pons, V.; Profeta, P.; Becher, M.; Brouard, S.; Foucault, M. Gender differences in COVID-19 attitudes and behavior: Panel evidence from eight countries. Proc. Natl. Acad. Sci. U. S. A. 2020, 117, 27285-27291, doi:10.1073/pnas.2012520117.

10. Abrams, E.M.; Greenhawt, M. Risk Communication During COVID-19. J. Allergy Clin. Immunol. Pract. 2020, 8, 1791-1794, doi:10.1016/j.jaip.2020.04.012.

11. Jungmann, S.M.; Witthöft, M. Health anxiety, cyberchondria, and coping in the current COVID-19 pandemic: Which factors are related to coronavirus anxiety? J. Anxiety Disord. 2020, 73, doi:10.1016/j.janxdis.2020.102239. 